\title{
Estimating the Impacts of Non-Tariff Measures in the Indian Ocean Rim Association
}

\author{
Abdallah Akintola ${ }^{1, * \mathbb{D}}$, Houcine Boughanmi ${ }^{1,2}$, Alessandro Antimiani ${ }^{3}$, Lokman Zaibet ${ }^{1}$ \\ and Hemesiri Kotagama 1 \\ 1 Department of Natural Resource Economics, College of Agricultural and Marine Science, Sultan Qaboos \\ University, Muscat 123, Oman; boughanh@squ.edu.om (H.B.); lzaibet@squ.edu.om (L.Z.); \\ hemkot@squ.edu.om (H.K.) \\ 2 WTO Chairs Programme, Sultan Qaboos University, Muscat 123, Oman \\ 3 Council for Agricultural Research and Agricultural Economics Analysis, 00198 Rome, Italy; \\ alessandroantimiani@gmail.com \\ * Correspondence: s117765@student.squ.edu.om
}

Citation: Akintola, A.; Boughanmi, H.; Antimiani, A.; Zaibet, L.;

Kotagama, H. Estimating the Impacts of Non-Tariff Measures in the Indian Ocean Rim Association. Sustainability 2022, 14, 68. https://doi.org/ $10.3390 /$ su14010068

Academic Editor: Jacob Arie Jordaan

Received: 6 October 2021

Accepted: 2 December 2021

Published: 22 December 2021

Publisher's Note: MDPI stays neutral with regard to jurisdictional claims in published maps and institutional affiliations.

Copyright: (c) 2021 by the authors. Licensee MDPI, Basel, Switzerland. This article is an open access article distributed under the terms and conditions of the Creative Commons Attribution (CC BY) license (https:/ / creativecommons.org/licenses/by/ $4.0 /)$.

\begin{abstract}
In recent years, the Indian Ocean Rim Association has witnessed an increasing trend in the use of non-tariff measures (NTMs). This study evaluated the impact of NTMs in the Indian Ocean Rim Association through estimations of their ad valorem equivalents at the HS chapter and country levels. A gravity model using NTM count data (intensity) was specified and estimated to derive the importer-specific ad valorem equivalents for the four (4) most used NTMs in the region. The results showed the presence of both import-impeding and import-promoting effects of NTMs; however, the import-impeding effects dominated in the region. The quantitative restriction and safeguard measures were more restrictive compared to the sanitary and phytosanitary measures and technical barriers to trade. This was expected since quantitative restrictions are trade-distorting by design. This calls for reforming trade policy in the region toward NTMs that are more transparent and trade enhancing for successful subsequent trade negotiations in the Indian Ocean Rim Association, which would support the sustainable economic development of the region.
\end{abstract}

Keywords: ad valorem equivalent; non-tariff measures; gravity model; IORA

\section{Introduction}

In the last three decades, the world has witnessed a dramatic increase in international trade, with many countries trading unilaterally and multilaterally. International trade has grown twice as much has global production [1], with total merchandise trade reaching USD 34.9 trillion in 2017 [2]. This growth was partly linked to the rapid technological development across the globe, the process of trade liberalization under the multilateral trading system (WTO), and the proliferation of regional trade integration arrangements (RTAs). The process of multilateral trade liberalization has been successful in significantly reducing import tariffs, which currently stand at an average below 5\% globally [3]. However, non-tariff measures (NTMs) are on the rise and can hinder trade-driven sustainable economic development. NTMs can directly or indirectly impact sustainable development. Direct impact involves policies with a direct effect on sustainability, such as protecting health and the environment, while indirect impact involves policies that affect trade and their effects spill over to sustainable development [4,5]. There is a growing literature that matches NTMs to the goals of sustainable development [5-8]. For example, the removal of burdensome NTMs in agrifood trade is expected to enhance sustainable world food security [9].

Non-tariff measures comprise a vast array of technical and non-technical government measures that can alter the volume, direction and composition of trade in a distortionary or promoting manner [10]. For example, some technical NTMs, such as sanitary and phytosanitary agreements (SPS) or technical barriers to trade (TBT), are targeted at protecting plant 
and human health and the environment, as well as mitigating information asymmetries and ensuring better import quality [11-14]. Furthermore, some countries make use of NTMs as political instruments (retaliatory) to restrict trade from countries that engage in trade wars with them $[15,16]$. The use of NTMs is regulated at the multilateral level by three agreements: TBT, SPS and, more recently, the trade facilitation agreement (TFA). The latter agreement is expected to significantly boost global trade as it directly addresses trade inefficiencies that are generated at the border by non-tariff barriers, such as customs red tape and poorer trade logistics.

The incidence of NTMs is on the rise in the Indian Ocean Rim Association (IORA) [17]. The trade structures and geographical and economic diversity of IORA countries vary their capacities to manage the economic implications of the protective measures of NTMs. The strategic address of the protective and distortionary measures of NTMs is expected to foster intra-regional trade (IRT) and promote further regional integration in the IORA [18,19]. The present framework of open regionalism (open regionalism is a form of regional economic integration that does not discriminate against economies outside the region, where countries are free to embark on an individual trade agreement with non-members) and the overlap of various trade agreements might undermine the process of tariff reduction and harmonization in the region. Nevertheless, much can be gained if the focus is on the reduction of NTMs [10] and strengthening the soft component of open regionalism, which involves trade facilitation and economic and technical cooperation [20,21].

In the past, studies about the NTMs of the IORA were addressed qualitatively without quantitative estimation, suggesting that there is still a knowledge gap that needs to be filled concerning the impact of NTMs on trade within the region. To the best of our knowledge, there has not been any study that estimated the ad valorem equivalent (AVE) of NTMs in the IORA. We expect that the estimation of importer-specific AVEs of NTMs in the IORA would contribute to a better understanding of the trade cost in the region and provide research-based information to the ongoing negotiation process of reducing trade costs.

The next section presents a brief background about the IORA and the prevalence of NTMs in the region. Section 3 describes the model, the underlying estimation issues and the data that was used in the analysis. Section 4 discusses the results and their implications, while Section 5 concludes the paper.

\section{IORA and NTMs Incidence}

The Indian Ocean is one of the fast-growing regions in the world and has always been a conduit for trade within Asia, the Middle East and Africa. Half of the world's container ships transit in this region, with strong future growth prospects [22]. The IORA is a regional economic association that operates on the principle of open regionalism to promote economic and sustainable growth through open trade and investment facilitation. The IORA includes countries from various geographical regions and continents (GCC, Africa and South and East Asia) with varying incomes, development levels, populations and factor endowments (Appendix A, Table A1).

Intra-regional trade has been quite robust in the IORA, despite the non existence of a legally binding regulating trade agreement in the region. However, the intra-regional trade level is relatively low compared to other trade blocs, such as the European Union (EU), North America Free Trade Agreement (NAFTA) and the Asia-Pacific Economic Cooperation (APEC) (APEC also operates based on open regionalism principles) [23]. Commitments by member countries to harmonize trade policy concerning tariffs, non-tariff barriers (NTBs), customs and other trade measures would potentially enhance regional integration and reduce the intra-regional trade performance gap [24]. It is expected that a deeper economic integration by the IORA members would increase the total and agricultural trade by 55 and $90 \%$, respectively, and is equivalent to cutting ad valorem tariffs by 10.3 and $14.9 \%$ for both types of trade, respectively [23]. 
The incidence of NTMs within the Indian Ocean is relatively high based on the notification of NTMs reported to WTO. WTO requires member countries to notify their NTM cases to ensure transparency and improve global trade. About $18 \%$ of the global notifications of NTMs were reported by IORA countries (Table 1).

Table 1. Comparison of NTM notifications.

\begin{tabular}{cccccccccccc}
\hline & \multicolumn{8}{c}{ Percentage of IORA Notifications Compared to World Notifications } \\
\hline Measures & SPS & TBT & ADP & CV & SG & SSG & QR & TRQ & XS & Total \\
\hline IORA & 1822 & 3607 & 538 & 29 & 3 & & 557 & 98 & 45 & 7227 \\
World & 15,145 & 19,256 & 1980 & 234 & 12 & 1379 & 1821 & 1279 & 379 & 41,289 \\
Percent & 12.03 & 18.73 & 27.17 & 12.39 & 25.00 & 0.00 & 30.59 & 7.66 & 11.87 & 17.50 \\
\hline \multicolumn{7}{c}{ Notification of Agricultural Products as a Percentage of Total Products in the IORA } \\
\hline Agricultural Products & SPS & TBT & ADP & CV & SG & SSG & QR & TRQ & XS & Total \\
Total Products & 1656 & 1414 & 25 & 6 & & & 175 & 94 & 38 & 3291 \\
Percent & 1822 & 3607 & 538 & 29 & 3 & & 557 & 98 & 45 & 7227 \\
\hline
\end{tabular}

ADP-anti-dumping, CV—countervailing, QR—quantitative restrictions, SG—safeguards, SPS—sanitary and phytosanitary, SSG — special safeguards, TBT—-technical barriers to trade, TRQ—tariff-rate quotas, XS—export subsidies. Source: Authors' calculation based on the WTO Integrated Trade Intelligence Portal (I-TIP) as of 2020.

In the IORA, TBT is the most applied form of NTM, followed by SPS measures (Figure 1). However, the agricultural sector had more incidences of SPS than TBT measures. The agricultural sector accounted for 39\% of the total incidence of NTMs in the region, following the global trend of the intensive use of NTMs on agri-foods products (Figure 2) compared to manufacturing products [25].

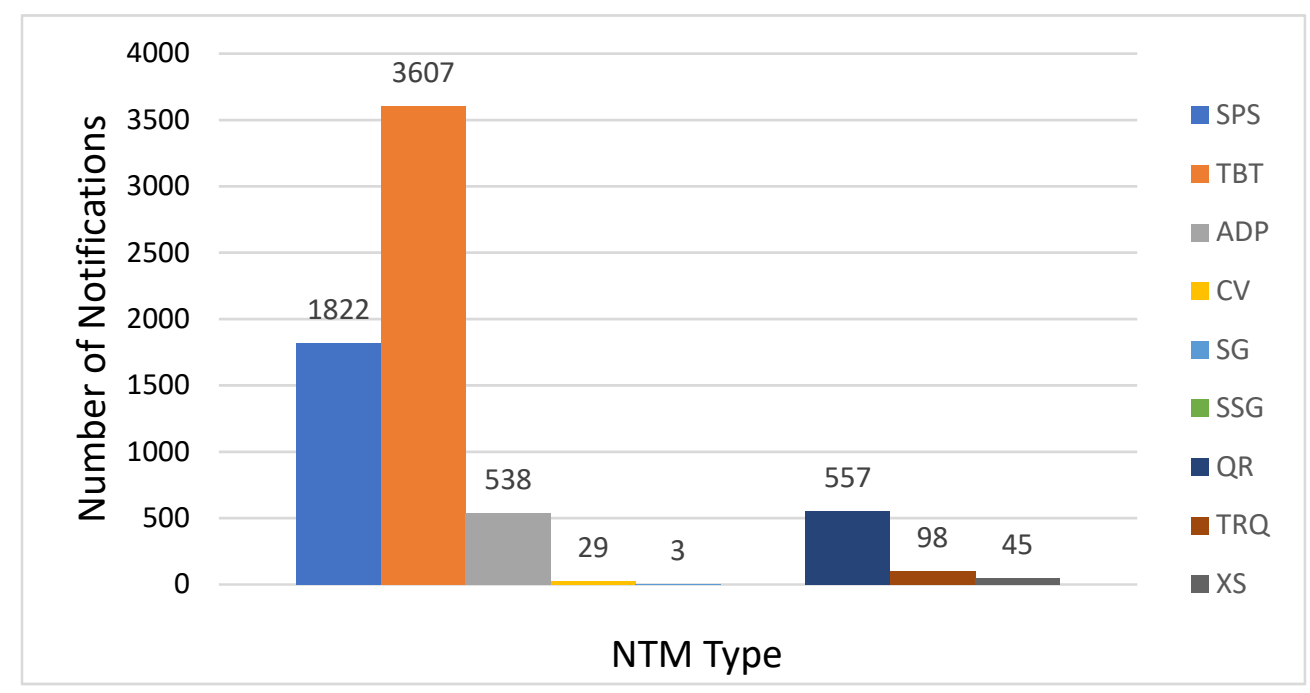

Figure 1. Number of NTM notifications in the IORA as of 2020. Source: Authors' calculations based on the WTO Integrated Trade Intelligence Portal. 


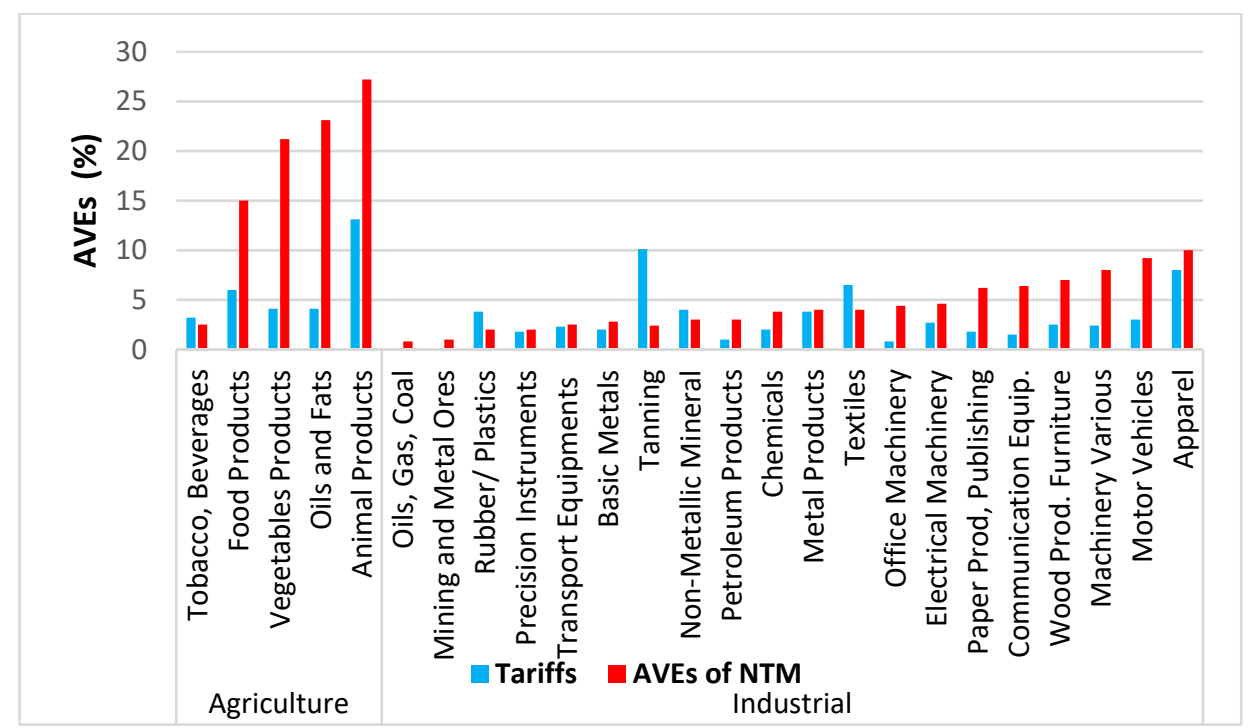

Figure 2. World tariffs and AVEs of NTMs by economic sector. Source: UNCTAD 2017 report of NTMs.

\section{Model}

There are two approaches, direct and indirect, that can be taken when estimating the AVEs of NTMs [26]. The direct method makes use of the handicraft approach and a combination of handicraft and econometric approaches. The handicraft approach involves removing all factors other than NTMs that impact domestic prices and would result in an accurate estimation of the NTM ad valorem equivalent. Breaux et al. [27] are among the few that applied this approach.

The indirect approach involves a two-stage computation for obtaining AVE. The first stage derives the impact on the quantity of trade with and without an NTM, while the second stage converts the impact on the quantity of trade into AVE using the import demand elasticities. This method was developed by Kee et al. [28] but it constrains NTMs to non-negative values, which portray only the trade-impeding effect of NTMs. The effect of an NTM on trade is ambiguous, as it can be trade-facilitating (increase demand) in the presence of positive externalities or trade hindering when it is used as a protective measure. As a result, subsequent studies, such as Beghin et al. [11] and Ghodsi et al. [29], employed unconstrained estimation, which allowed for both positive and negative AVEs, where trade-promoting and trade-restricting effects of NTMs are captured.

A large strand of empirical research has relied on the gravity model when estimating the AVEs of NTMs, despite the increasing prevalence of NTMs and data limitations [30]. This research followed suit and built on the work of Kee et al. [31] and Ghodsi et al. [29] to estimate the AVEs by employing an intensity measure (count number) when capturing the NTMs that were notified to WTO.

The ad valorem equivalent estimation followed a two-stage approach. First, the effect of NTMs on the import demand was estimated using an augmented structural gravity model, followed by transforming the estimates into AVEs. The Poisson pseudo maximum likelihood (PPML) estimator was used for gravity estimation as it resolves issues arising from the presence of zero trade and produces consistent estimates that are easy to interpret [32-34]. As most NTMs are not bilateral, we employed the importer-specific augmented structural gravity model in the logarithmic form as follows:

$$
\operatorname{lnc} c_{i j k}=\beta_{o h}+\beta_{1 k} \ln \left(1+\tau_{i j k-1}\right)+\sum_{n=1}^{N-1} \beta_{2 k}^{n} M_{j k t-1}^{T}+\sum_{i=1}^{n} \beta_{3 j k}^{n}\left(\omega_{1} M_{j k t-1}^{T}\right)+\beta_{4 k}^{n} x_{j k t-1}+\delta_{i}+\delta_{j}+\delta_{t}+u_{i j k t-1}
$$


$\ln c_{i j k}$ is the import value, where $i$ and $j$ indicate the origin and destination of product $k$ (chapter level HS-2 digit) at time $t . M_{j k t-1}^{T}$ captures the count of an NTM type during the period $t-1$, while $\tau_{i j k t-1}$ denotes the bilateral ad valorem tariff imposed by $j$ on imports of $k$ from $i . \omega_{1} M_{j k t-1}^{T}$ is an integer variable that captures the interaction of NTM counts and factor endowments, $x_{j k t-1}$ is a vector of time-varying country-pair characteristics, factor endowment and WTO membership. $\delta_{i}, \delta_{j}$ and $\delta_{t}$ reflect the exporter, importer and time dimensionality, respectively, and help to take care of the multilateral resistance effect [35-37]. Furthermore, the explanatory variables were lagged by a year in order to minimize the endogeneity bias that might result from including policy variables as regressors that often take time before the effects are noticed on demand [29]. The regression equation was carried out at the chapter level of the harmonized system (HS-2 96 chapters) and country-level (the country-pair time effect was used in the country gravity estimation). $\beta^{\mathrm{n}}{ }_{2 \mathrm{k}}$ and $\beta^{\mathrm{n}}{ }_{3 \mathrm{k}}$ capture the direct and interaction effects of NTMs on import values. The trade impact coefficients $\left(\beta^{\mathrm{n}}{ }_{2 \mathrm{k}}, \beta^{\mathrm{n}}{ }_{3 \mathrm{k}}\right)$ were later inputted into Equation (2) below to estimate the AVEs of NTMs for the IORA importing country $\left(A V E_{\text {country }}\right)$ and chapter $\left(A V E_{\text {chapter }}\right)$. The import demand elasticity, de, was taken from Ghodsi et al. [38].

$$
A V E_{\text {Chapter }}=\frac{\left[\exp \left(\beta_{2 k}^{n}+\beta_{3 j k}^{n}\right)-1\right]}{d e} \times 100
$$

Data

The analysis was limited to eleven IORA countries due to data availability. The data that were retrieved from the wiiw database provided NTMs information for only 11 out of the 22 IORA countries. The harmonized system (HS) revision 2002 was used to ensure consistency of the trade import data and the NTMs (Appendix A, Table A2) data ranging from 2009 to 2015. Trade import value data and ad valorem tariffs were retrieved from World Bank's World Integrated Trade Solution (WITS). Information on NTMs was pooled from the wiiw database based on an extensive compilation done by Ghodsi et al. [39]. This NTM database was favoured because it is a compilation of NTMs from the World Trade Organization (WTO) and the Integrated Trade Intelligence Portal (I-TIP), which allows for variation in NTM types and NTMs in a continuous form. Only measures of SPS, TBT, QR and SG were considered. The NTMs provided by wiiw were in HS-6 digit and we aggregated them to HS-2 digit using R software to suit the objective of the study. Data on factor endowment (labour and capital stock) were retrieved from the Penn World Tables (PWT 9.1) compiled by Feenstra et al. [40], while the relevant gravity variables (GDP and population) and agricultural land were retrieved from the CEPII and World Bank Indicator database (WDI), respectively.

\section{Results and Discussion}

Four main NTMs (SPS, TBT, QR and SG) were considered in the analysis based on their prevalence in the IORA region. Our results included both positive and negative AVE estimates, allowing for the evaluation of whether NTMs had import-promoting or import-reducing effects at the country and chapter levels $[7,8,21]$. Of the total expected AVE estimates, we were only able to retrieve around $36.5 \%$ that were binding and significant at the $10 \%$ level. Positive AVEs indicate the price-raising effect of NTMS, signalling strong import quality and consumer satisfaction when SPS and TBT measures are considered [14]. It should also be noted that the NTM effect depends on the commodity and the country been analysed [41].

\subsection{Country-Level AVE}

Only 11 countries were considered in the estimation of the country-level AVEs. The impact of NTMs varies by country depending on prevailing trade and economic structure and the intended purpose of the NTM in place [29]. The results indicated that the imposed SPS measures were mostly import-restricting effects, while the TBT measures had an 
import-facilitating effect across all countries (Table 2). The TBT AVEs varied from -0.09 in South Africa to -87 in UAE. The import-facilitating impact of TBT might suggest that IORA countries impose such technical measures to increase the quality of imports and information that is available to consumers. As most of the SPS measures were applied to the agricultural sector, their import-restricting effect may suggest that SPS in the IORA were used as a protective substitute for the declining use of tariffs in the sector. In addition, the restrictive effect of SPS seemed to be higher overall in the high-income countries of the region (Singapore, Oman and Malaysia) than in middle- and low-income countries.

Table 2. AVEs of the IORA countries.

\begin{tabular}{cccccc}
\hline Importer & SPS & TBT & QR & SG & Tariff \\
\hline UAE & 0.026 & -87.007 &. & -4.396 & 4.5 \\
Australia & 0.055 & -0.164 & -0.007 &. & 2 \\
Indonesia & 0.009 & -0.046 & $\cdot$ & -0.702 & 5 \\
India & -0.028 & -0.012 &. & -0.881 & 12.8 \\
Kenya & 0.005 & -0.009 & $\cdot$ &. & 9.2 \\
Mauritius & -0.142 &. & $\cdot$ &. & 0.6 \\
Malaysia & 0.487 & -0.444 &. &. & 4.5 \\
Oman & 0.400 & -1.618 &. & 37.885 & 4.6 \\
Singapore & 95.771 &. &. &. & 0 \\
Tanzania & & -0.698 & $\cdot$ & -8.250 & 9.7 \\
South Africa & -0.010 & -0.019 &. & 6.3 \\
\hline
\end{tabular}

PPML estimations were significant at least $p<0.10$ level. Note: The country-pair time effects and tariffs were computed.

\subsection{Chapter-Level AVE in the IORA}

The trade impacts of NTMs depend on the type of product and level of aggregation used in the analysis (chapter level in our case). The results are reported based on the HS-2 chapter (Appendix A, Table A3), HS economic sector (Table 3) and sector level (Appendix A, Table A4). In general, there were twice as many positive AVEs indicating import-restriction effects than negative ones (Table 3). These results were in line with those obtained by Ghodsi et al., where the AVEs varied in both positive and negative directions.

Table 3. AVEs of the IORA NTMs by HS economic sector.

\begin{tabular}{|c|c|c|c|c|c|}
\hline & Description & SPS & TBT & QR & SG \\
\hline I: $(01-05)$ & Live animals and products & 0.011 & -0.020 & 0.658 & \\
\hline II: $(06-14)$ & Vegetable products & -0.004 & 0.082 & 0.141 & -0.071 \\
\hline III: (15-15) & Animal and vegetable fats, oils and waxes & & . & -0.019 & . \\
\hline IV: (16-24) & Prepared foodstuffs, bevearges, spirits, vinegar and tobacco & -0.232 & -0.033 & 6.114 & 4.490 \\
\hline $\mathrm{V}:(25-27)$ & Mineral products & 0.057 & 0.020 & 0.054 & . \\
\hline VI: (28-38) & Products of chemical and allied industries & 21.817 & -0.012 & 1.878 & -4.494 \\
\hline VII: (39-40) & Resins, plastics and articles and rubber and articles & & -0.021 & 0.199 & 1.922 \\
\hline VIII: $(41-43)$ & Hides, skins and articles, saddlery and travel goods & -1.771 & 0.071 & 1.251 & \\
\hline IX: $(44-46)$ & Wood, cork and articles and basket wares & & 0.240 & & -0.923 \\
\hline$X:(47-49)$ & Paper, paperboard and articles & 0.232 & 0.259 & 1.687 & 12.546 \\
\hline XI: (50-63) & Textiles and articles & 0.976 & 0.032 & -0.525 & -3.260 \\
\hline XII: (64-67) & Footwear, headgear, feathers, artificial flowers and fans & -0.107 & 0.001 & 4.171 & \\
\hline XIII: (68-70) & Articles of stones, plaster, ceramic products and glass & & -0.005 & & \\
\hline XIV: (71-71) & Pearls, precious stones and metals and coins & & & & \\
\hline $\mathrm{XV}:(72-83)$ & Base metals and articles & 0.263 & -0.062 & 0.640 & -0.415 \\
\hline XVI: (84-85) & Machinery and electrical equipment & & -0.004 & & \\
\hline XVII: (86-89) & Vehicles, aircraft and vessels & -3.594 & -3.496 & -0.745 & -1.050 \\
\hline XVIII: (90-92) & Instruments, clocks, recorders and reproducers & & -0.004 & 0.785 & -2.034 \\
\hline XIX: (93-93) & Arms and ammunition & & 0.278 & & \\
\hline XX: (94-96) & Miscellaneous manufactured articles & -46.767 & -0.015 & 0.593 & \\
\hline XXI: (97-97) & Works of art and antiques & & & & \\
\hline
\end{tabular}


Considering the overall binding AVE (Appendix A, Table A3), the SPS measure had the highest and lowest binding AVEs. For the SPS measure, the highest AVE was for albuminoidal substances (HS 35: AVE of 67), followed by cotton (HS 52: AVE of 3) and the lowest was furniture (HS 94: AVE of -47). Regarding the TBT measure, nickel and articles thereof (HS 75: AVE of 0.77) had the highest AVE, closely followed by wood pulp (HS 47: AVE of 0.76), while the lowest was railway or tramway locomotives (HS 86: AVE of -6.9). The QR measure had the highest AVE for tobacco (HS 24: AVE of 36) and the lowest for residues and waste from food industries (HS 23: AVE of -12.5). The results for the SG measures indicated that paper and paperboard (HS 48: AVE of 12.6) obtained the highest AVE and "Other made-up textile articles" (HS 63: AVE of -7) had the lowest AVE.

At the HS economic sector level (Table 3), we observed the import-restricting effect for paper, paperboard and articles (X: (HS 47-49)) and prepared foodstuffs, beverages, spirits, vinegar and tobacco (IV: (HS 16-24)). This might indicate the existence of strong trade barriers. As for vehicles, aircraft and vessels (XVII: (HS 86-89)), we observed an import-promoting effect with negative AVEs.

The results for the sectoral level for agriculture (Appendix A, Table A4) showed, on average, a high AVE for QR and SG measures as opposed to SPS and TBT, despite their high incidence on agricultural products in the IORA. High numbers of specific NTMs might be imposed but do not necessarily translate to strong restrictions, i.e., high AVEs of such NTMs. This might suggest that import quota and contingent trade protection measures were still rampant in the region, probably as a way of protecting the domestic agricultural industries. High AVEs of concern in the agricultural sector, based on the QR and SG measures, were discovered for tobacco, preparation of vegetables, dairy produce and cereals. For the manufacturing product, we found more positive AVEs than negative ones, with albuminoidal substances, headgear, and cotton having high import-restricting effects on them. The manufacturing sector also showed a high AVE on average for QR, which could be linked to its high incidence, as shown in Table 1.

Overall, the observed differences in the AVE estimates might have been due to the product aggregation, the small number of years covered and the small number of countries included in the analysis (due to data paucity).

\section{Conclusions}

This study aimed to contribute to the empirical literature on the quantification of NTMs in the IORA region by estimating the AVEs of four specific NTMs (SPS, TBT, QR and SG) at the country, product and sector levels. The research method that was used in the analysis followed recent studies, employing an intensity measure of NTMs rather than the conventional dummy variable method. The method allowed for distinguishing the import-promoting and import-restricting effects of specific NTMs.

Overall, the results indicated that NTMs in the IORA were more trade-restricting than trade-promoting, which could have an impact on sustainable economic development through trade. The quantitative and contingent measures were found to be more restrictive than SPS and TBT. At the product level, the results showed that trade in agricultural and food products were negatively affected by NTMs, mostly in the form of quantitative restriction and safeguard measures, despite the prevalence of the SPS measures in agriculture. This area requires more investigation and calls for attention, as contingent measures are more trade-distorting, and understanding their impacts is crucial to future trade agreements in the region. At the country level, we observed high restrictiveness of SPS measures for high-income countries as compared to middle- and low-income countries.

The results that were obtained in this research needed to be interpreted with some precaution due to the limited number of countries covered in the study. Further research is needed to understand the trade effect of NTMs by increasing the countries and years covered. Since this study was carried at a highly aggregated level (HS-2 digit), future studies can be conducted at a more disaggregated level (HS-6 digit) to fully understand the 
impact of various NTMs on various products. In addition, it would be useful to thoroughly empirically consider the impact of NTMs on sustainability within the IORA.

Author Contributions: Conceptualization, A.A. (Abdallah Akintola), H.B. and H.K; methodology, A.A. (Abdallah Akintola) and H.B; software, A.A. (Abdallah Akintola); formal analysis, A.A. (Alessandro Antimiani); writing-original draft preparation, A.A. (Abdallah Akintola); writingreview and editing, H.B., L.Z. and H.K. All authors have read and agreed to the published version of the manuscript.

Funding: This research received no external funding.

Institutional Review Board Statement: Not applicable.

Informed Consent Statement: Not applicable.

Data Availability Statement: Not applicable.

Conflicts of Interest: The authors declare no conflict of interest.

\section{Appendix A}

Table A1. IORA countries income and regional classifications.

\begin{tabular}{|c|c|c|}
\hline Region & Countries & Income Level \\
\hline Australasia & Australia & High \\
\hline \multirow[t]{4}{*}{ Southeast Asia } & Indonesia & Upper Middle \\
\hline & Malaysia & Upper Middle \\
\hline & Singapore & High \\
\hline & Thailand & Upper Middle \\
\hline \multirow[t]{4}{*}{ South Asia } & Bangladesh & Lower Middle \\
\hline & India & Lower Middle \\
\hline & Maldives & Upper Middle \\
\hline & Sri Lanka & Lower Middle \\
\hline \multirow[t]{4}{*}{ West Asia } & Iran & Upper Middle \\
\hline & Oman & High \\
\hline & UAE & High \\
\hline & Yemen & Low \\
\hline \multirow[t]{7}{*}{ Eastern Africa } & Comoros & Low \\
\hline & Kenya & Lower Middle \\
\hline & Madagascar & Low \\
\hline & Mauritius & High \\
\hline & Seychelles & High \\
\hline & Somalia & Low \\
\hline & Tanzania & Lower Middle \\
\hline \multirow[t]{3}{*}{ Southern Africa } & Mozambique & Low \\
\hline & South Africa & Upper Middle \\
\hline & France (Reunion Island) & \\
\hline
\end{tabular}


Table A2. Non-tariff measures classifications.

\begin{tabular}{|c|c|c|}
\hline \multicolumn{3}{|c|}{ Imports } \\
\hline \multirow{7}{*}{ Non-Technical Measures } & A & Sanitary and Phytosanitary Measures \\
\hline & $\mathrm{B}$ & Technical Barriers to Trade \\
\hline & $\mathrm{C}$ & Pre-Shipment Inspection and Other Formalities \\
\hline & $\mathrm{D}$ & Contingent Trade-Protective Measures \\
\hline & $\mathrm{E}$ & $\begin{array}{l}\text { Non-Automatic Licensing, Quotas, Prohibitions } \\
\text { and Quantity-Control Measures Other Than for } \\
\text { SPS or TBT Reasons }\end{array}$ \\
\hline & $\mathrm{F}$ & $\begin{array}{c}\text { Price-Control Measures, Including Additional } \\
\text { Taxes and Charges }\end{array}$ \\
\hline & G & Finance Measures \\
\hline & $\mathrm{H}$ & $\begin{array}{c}\text { Measures Affecting Competition Procurement } \\
\text { Restrictions, Intellectual Property and Rules } \\
\text { of Origin }\end{array}$ \\
\hline & I & Trade-Related Investment Measures \\
\hline & $\mathrm{J}$ & Distribution Restrictions \\
\hline & $\mathrm{K}$ & Restrictions on Post-Sales Services \\
\hline & $\mathrm{L}$ & Subsidies (Excluding Export Subsidies Under P7) \\
\hline & $\mathrm{M}$ & Government Procurement Restrictions \\
\hline & $\mathrm{N}$ & Intellectual Property \\
\hline & $\mathrm{O}$ & Rules of Origin \\
\hline \multicolumn{3}{|c|}{ Exports } \\
\hline & $\mathrm{P}$ & Export-Related Measures \\
\hline
\end{tabular}

Source: UNCTAD 2015.

Table A3. AVEs of NTMs at the HS chapter level.

\begin{tabular}{|c|c|c|c|c|c|}
\hline HS 2 & Description & SPS & TBT & QR & SG \\
\hline 1 & Live animals and products & 0.020 & -0.087 & 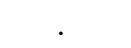 & . \\
\hline 2 & Meat and edible meat offal & • & -0.003 & -1.338 & . \\
\hline 3 & Fish and crustaceans, molluscs, ... & 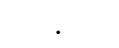 & -0.002 & . & . \\
\hline 4 & Dairy produce, birds' eggs, ... & 0.002 & -0.008 & 3.164 & . \\
\hline 5 & Products of animal origin, ... & & 0.000 & 0.147 & . \\
\hline 6 & Live trees and other plants, ... & & . & . & . \\
\hline 7 & Edible vegetables and certain ... & -0.004 & 0.003 & . & . \\
\hline 8 & Edible fruit and nuts, $\ldots$ & . & -0.002 & . & . \\
\hline 9 & Coffee, tea, ... & . & . & . & . \\
\hline 10 & Cereals & 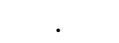 & -0.045 & 1.582 & . \\
\hline 11 & Products of the milling industry, ... & -0.005 & 0.004 & . & -0.071 \\
\hline 12 & Oilseeds and oleaginous fruits, ... & . & . & -0.291 & . \\
\hline 13 & Lac, gums, resins, ... & . & . & -0.867 & . \\
\hline 14 & Vegetable plaiting materials, ... & & 0.449 & . & . \\
\hline 15 & Animal or vegetable fats and oils, ... & . & . & -0.019 & . \\
\hline 16 & Preparations of meat, of fish, ... & -0.016 & -0.010 & -5.161 & . \\
\hline 17 & Sugars and sugar confectionery & 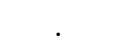 & -0.021 & . & . \\
\hline 18 & Cocoa and cocoa preparations & -0.043 & . & . & . \\
\hline 19 & Preparations of cereals, flour, ... & 0.006 & 0.000 & . & . \\
\hline 20 & Preparations of vegetables, ... & $\cdot$ & -0.005 & . & 4.490 \\
\hline 21 & Miscellaneous edible preparations & 0.029 & -0.015 & . & . \\
\hline 22 & Beverages, spirits and vinegar & & -0.006 & 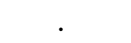 & . \\
\hline 23 & Residues and waste from ... & 0.005 & -0.007 & -12.529 & . \\
\hline 24 & Tobacco and manufactured ... & -1.376 & -0.196 & 36.032 & . \\
\hline 25 & Salt, sulfur, earth and stone, ... & 0.057 & -0.002 & 0.054 & . \\
\hline 26 & Ores, slag and ash & . & . & . & . \\
\hline 27 & Mineral fuels, mineral oils, ... & . & 0.041 & . & . \\
\hline 28 & Inorganic chemicals, organic ... & . & . & 0.064 & . \\
\hline
\end{tabular}


Table A3. Cont.

\begin{tabular}{|c|c|c|c|c|c|}
\hline HS 2 & Description & SPS & TBT & QR & SG \\
\hline 29 & Organic chemicals & . & & -0.007 & -0.333 \\
\hline 30 & Pharmaceutical products & . & -0.026 & -0.035 & . \\
\hline 31 & Fertilizers & . & . & 0.703 & . \\
\hline 32 & Tanning or dyeing extracts, ... & -1.838 & - & . & . \\
\hline 33 & Essential oils and resinoids, ... & . & -0.001 & . & . \\
\hline 34 & Soap, organic surface-active ... & . & -0.024 & 0.637 & . \\
\hline 35 & Albuminoidal substances, ... & 67.224 & & 11.209 & -8.655 \\
\hline 36 & Explosives, pyrotechnics, ... & . & 0.028 & 0.572 & . \\
\hline 37 & Photographic or cinematographic ... & . & . & . & . \\
\hline 38 & Miscellaneous chemical products & 0.065 & -0.036 & . & . \\
\hline 39 & Plastics and articles thereof & . & . & 0.169 & . \\
\hline 40 & Rubber and articles thereof & . & -0.021 & 0.230 & 1.922 \\
\hline 41 & Raw hides and skins ... & . & 0.004 & 1.918 & . \\
\hline 42 & Articles of leather, saddlery, ... & . & 0.138 & . & . \\
\hline 43 & Furskins and artificial fur, ... & -1.771 & . & 0.584 & . \\
\hline 44 & Wood and articles of wood, ... & . & 0.062 & . & -0.923 \\
\hline 45 & Cork and articles of cork & . & . & . & . \\
\hline 46 & Manufactures of straw, ... & . & 0.418 & . & . \\
\hline 47 & Pulp of wood or other fibrous ... & . & 0.762 & . & . \\
\hline 48 & Paper and paperboard, ... & 0.232 & 0.017 & 0.141 & 12.546 \\
\hline 49 & Printed books, newspapers, ... & . & 0.000 & 3.233 & . \\
\hline 50 & Silk & . & 0.040 & . & . \\
\hline 51 & Wool, fine or coarse ... & . & . & 1.729 & . \\
\hline 52 & Cotton & 3.000 & . & 0.339 & -0.232 \\
\hline 53 & Other vegetable textile fibres, . & . & . & -4.476 & . \\
\hline 54 & Man-made filaments & . & -0.032 & -0.545 & . \\
\hline 55 & Man-made staple fibers & . & 0.000 & . & . \\
\hline 56 & Wadding, felt and nonwovens, ... & . & . & . & . \\
\hline 57 & Carpets and other textile floor... & . & 0.043 & . & . \\
\hline 58 & Special woven fabrics, ... & . & . & . & . \\
\hline 59 & Impregnated, coated, covered ... & . & . & . & -2.344 \\
\hline 60 & Knitted or crocheted fabrics & . & 0.095 & . & . \\
\hline 61 & Articles of apparel and clothing ... & -0.046 & . & -0.013 & . \\
\hline 62 & Articles of apparel and clothing ... & -0.025 & . & -0.186 & . \\
\hline 63 & Other made-up textile articles, ... & . & 0.045 & . & -7.205 \\
\hline 64 & Footwear, gaiters and the like, ... & -0.107 & . & 0.872 & . \\
\hline 65 & Headgear and parts thereof & . & 0.161 & 7.469 & . \\
\hline 66 & Umbrellas, sun umbrellas, ... & . & 0.537 & . & . \\
\hline 67 & Prepared feathers ... & . & -0.694 & . & . \\
\hline 68 & Articles of stone, plaster, ... & . & -0.005 & . & . \\
\hline 69 & Ceramic products & . & . & . & . \\
\hline 70 & Glass and glassware & . & . & . & . \\
\hline 71 & Natural or cultured pearls, ... & . & . & . & . \\
\hline 72 & Iron and steel & . & . & -0.279 & . \\
\hline 73 & Articles of iron or steel & 0.263 & . & . & -0.415 \\
\hline 74 & Copper and articles thereof & . & -0.130 & . & . \\
\hline 75 & Nickel and articles thereof & . & 0.775 & 0.077 & . \\
\hline 76 & Aluminum and articles thereof & . & -0.103 & . & . \\
\hline 78 & Lead and articles thereof & . & . & . & . \\
\hline 79 & Zinc and articles thereof & . & $\cdot$ & . & . \\
\hline 80 & Tin and articles thereof & . & -0.896 & 2.122 & . \\
\hline 81 & Other base metals, cermets, ... & . & 0.203 & . & . \\
\hline 82 & Tools, implements, cutlery, ... & . & -0.038 & . & . \\
\hline 83 & Miscellaneous articles ... & . & -0.244 & . & . \\
\hline 84 & Nuclear reactors, boilers, ... & . & -0.004 & . & . \\
\hline 85 & Electrical machinery and equipment, ... & . & . & . & . \\
\hline 86 & Railway or tramway locomotives, ... & . & -6.851 & 2.626 & . \\
\hline
\end{tabular}


Table A3. Cont.

\begin{tabular}{|c|c|c|c|c|c|}
\hline HS 2 & Description & SPS & TBT & QR & SG \\
\hline 87 & Vehicles other than railway ... & -3.594 & . & . & -1.050 \\
\hline 88 & Aircraft, spacecraft, and ... & . & . & . & . \\
\hline 89 & Ships, boats and floating ... & . & -0.141 & -4.116 & . \\
\hline 90 & Optical, photographic ... & . & -0.004 & . & -2.034 \\
\hline 91 & Clocks and watches... & . & . & 0.785 & . \\
\hline 92 & Musical instruments, parts and ... & . & . & . & . \\
\hline 93 & Arms and ammunition, parts ... & . & 0.278 & . & . \\
\hline 94 & Furniture, bedding, mattresses, ... & -46.767 & -0.058 & . & . \\
\hline 95 & Toys, games and sports, ... & . & 0.027 & . & . \\
\hline 96 & Miscellaneous manufactured ... & . & . & 0.593 & . \\
\hline 97 & Works of art, collectors' pieces ... & . & . & . & . \\
\hline
\end{tabular}

Results significant at least at $p<0.10$ level.

Table A4. AVEs of NTMs at the sectoral level.

\begin{tabular}{ccccc}
\hline Sector & SPS & TBT & QR & SG \\
\hline Agrifood & -0.138 & 0.003 & 2.072 & 2.210 \\
Manufacturing & 1.284 & -0.144 & 0.913 & -0.793 \\
\hline Note: Calculated based on simple averages. & &
\end{tabular}

\section{References}

1. WTO. World Trade Report 2013: Factors Shaping the Future of World Trade; World Trade Organization: Geneva, Switzerland, 2013.

2. UNCTAD. International Trade Statistics Yearbook, 2017; United Nations Conference on Trade and Development: Geneva, Switzerland, 2017.

3. Disdier, A.-C.; Fontagné, L.; Cadot, O. North-South standards harmonization and international trade. World Bank Econ. Rev. 2015, 29, 327-352. [CrossRef]

4. UNCTAD. Non-Tariff Measures and Sustainable Development Goals: Direct and Indirect Linkages; United Nations Conference on Trade and Development: Geneva, Switzerland, 2015.

5. Zainuddin, M.R.K.; Sarmidi, T.; Khalid, N. Sustainable production, non-tariff measures, and trade performance in RCEP countries. Sustainability 2020, 12, 9969. [CrossRef]

6. Sandaruwan, K.; Weerasooriya, S.A. Non-Tariff Measures and Sustainable Development: The Case of the European Union Import Ban on Seafood from Sri Lanka; ARTNeT Working Paper Series; ESCAP: Bangkok, Thailand, 2019.

7. Kravchenko, A.; Semenova, M.; Lee, S.; Duval, Y. Exploring Linkages between Non-Tariff Measures and the Sustainable Development Goals: A Global Concordance Matrix and Application to Asia and the Pacific; ESCAP: Bangkok, Thailand, 2019.

8. Lee, S.; Prabhakar, D. COVID-19 Non-Tariff Measures: The Good and the Bad, Through a Sustainable Development Lens; UN: Geneva, Switzerland, 2021.

9. Council, A.B.A. Non-Tariff Barriers in Agriculture and Food Trade in APEC: Business Perspectives on Impacts and Solutions. University of Southern California. 2016. Available online: https://www.ncapec.org/docs (accessed on 10 June 2021).

10. UNCTAD. Non-Tariff Measures to Trade: Economic and Policy Issues for Developing Countries; United Nations Conference on Trade and Development: Geneva, Switzerland, 2013.

11. Beghin, J.C.; Disdier, A.C.; Marette, S. Trade restrictiveness indices in the presence of externalities: An application to non-tariff measures. Can. J. Econ. Rev. Can. D'économique 2015, 48, 1513-1536. [CrossRef]

12. Bratt, M. Estimating the bilateral impact of non-tariff measures (NTMs)(No. 14011). Rev. Int. Econ. 2017, 25, 1105-1129. [CrossRef]

13. Ing, L.Y.; Cadot, O. Ad Valorem Equivalents of Non-Tariff Measures in ASEAN; ERIA: Jakarta, Indonesia, 2017.

14. Cadot, O.; Gourdon, J. NTMs, Preferential Trade Agreements, and Prices: New Evidence; CEPI: London, UK, 2015.

15. Nes, K.; Schaefer, K.A. Retaliatory Use of Public Standards in Trade; National Bureau of Economic Research: Cambridge, MA, USA, 2020.

16. UNCTAD. Asia-Pacific Trade and Investment Report 2019: Navigating Non-Tariff Measures towards Sustainable Development; United Nations Economic and Social Commission for Asia and the Pacific: Bangkok, Thailand, 2019; p. 130.

17. IORA. The Study On Bilateral and Regional Trade and Investment Related Agreements and Dialogues Between Member States; Indian Ocean Rim Association: Ebene, Mauritius, 2016.

18. Dabee, B.; Reddy, M. Regional agreements in the Indian ocean. World Econ. 2000, 23, 1149-1160. [CrossRef]

19. Anderson, K. Agricultural Trade Liberalization: Implications for Indian Ocean. Rim Countries; Centre for International Economic Studies: Adelaide, Australia, 2002.

20. Kelegama, S. Can Open Regionalism Work in the Indian Ocean Rim Association for Regional Co-operation? ASEAN Econ. Bull. 1998, 15, 153-167. [CrossRef] 
21. Kelegama, S. Open Regionalism in the Indian Ocean: How relevant is the APEC model for IOR-ARC? J. Asia Pac. Econ. 2000, 5, 255-274. [CrossRef]

22. Euromonitor. IORA Selected Economic Indicators; Indian Ocean Rim Association: Ebene, Mauritius, 2019.

23. Boughanmi, H.; Akintola, A.; Kotagama, H.; Zaibet, L. Looking East: Oman's trade integration in the Indian Ocean. Rim Association (IORA); Global Trade Analysis Project (GTAP): West Lafayette, IN, USA, 2019.

24. Mohanty, S.K.; Dash, P. Trade and Investment Prospects of the IORA in the New Millennium New Economic Frontiers of the Region; 2015. Available online: https:/ /iora.ris.org.in/trade-and-investment-prospects-iora-new-millennium-new-economicfrontiers-region (accessed on 2 May 2019).

25. UNCTAD; World Bank. The Unseen Impact of Non-Tariff Measures: Insights from a New Database; UNCTAD: Geneva, Switzerland, 2018.

26. Disdier, A.-C.; Fugazza, M. A Practical Guide to the Economic Analysis of Non-Tariff Measures; United Nations: Geneva, Switzerland, 2020.

27. Breaux, M.; Cabral, Y.; Signoret, J.; Ferrantino, M.J. Quality-Adjusted Estimates of NTM Price Gaps; US Internat. Trade Commission, Office of Economics: Washington, DC, USA, 2014.

28. Looi Kee, H.; Nicita, A.; Olarreaga, M. Estimating trade restrictiveness indices. Econ. J. 2009, 119, 172-199. [CrossRef]

29. Ghodsi, M.; Gruebler, J.; Stehrer, R. Estimating Importer-Specific ad Valorem Equivalents of Non-Tariff Measures; Wiiw Working Paper; The Vienna Institute for International Economic Studies: Vienna, Austria, 2016.

30. Nicita, A.; Jaime, D.E. Non-Tariff Measures: Data and Quantitative Tools of Analysis. 2018. Available online: https://ferdi.fr/dl/ df-pwFsQKwSBf2Djde77ELncfwt/ ferdi-p218-non-tariff-measures-data-and-quantitative-tools-of-analysis.pdf (accessed on 23 May 2019).

31. Kee, H.L.; Nicita, A.; Olarreaga, M. Ad Valorem Equivalents of Non-Tariff Barriers; World Bank: Washington, DC, USA, 2005.

32. Arvis, J.-F.; Shepherd, B. The Poisson quasi-maximum likelihood estimator: A solution to the 'adding up' problem in gravity models. Appl. Econ. Lett. 2013, 20, 515-519. [CrossRef]

33. Silva, J.S.; Tenreyro, S. The log of gravity. Rev. Econ. Stat. 2006, 88, 641-658. [CrossRef]

34. Yotov, Y.V.; Piermartini, R.; Monteiro, J.-A.; Larch, M. An Advanced Guide to Trade Policy Analysis: The Structural Gravity Model; World Trade Organization: Geneva, Switzerland, 2016.

35. Niu, Z.; Liu, C.; Gunessee, S.; Milner, C. Non-tariff and overall protection: Evidence across countries and over time. Rev. World Econ. 2018, 154, 675-703. [CrossRef]

36. Baier, S.L.; Bergstrand, J.H. Bonus vetus OLS: A simple method for approximating international trade-cost effects using the gravity equation. J. Int. Econ. 2009, 77, 77-85. [CrossRef]

37. Mátyás, L. Proper econometric specification of the gravity model. World Econ. 1997, 20, 363-368. [CrossRef]

38. Ghodsi, M.; Grübler, J.; Stehrer, R. Bilateral Import Elasticities of Demand; Wiiw: Vienna, Austria, 2016.

39. Ghodsi, M.; Reiter, O.; Stehrer, R. Compilation of a Database for Non-Tariff Measures from the WTO Integrated Trade Intelligence Portal (WTO I-TIP); Paper written in the PRONTO project, work in progress; wiiw: Vienna, Austria, 2015.

40. Feenstra, R.C.; Inklaar, R.; Timmer, M.P. The next generation of the Penn World Table. Am. Econ. Rev. 2015, 105, 3150-3182. [CrossRef]

41. Ronen, E. Quantifying the trade effects of NTMs: A review of the empirical literature. J. Econ. Political Econ. 2017, 4, 263-274. [CrossRef] 